\title{
Utilization of AHP-MAUT Method to Determine the Country of Exhibition Abroad in Batik Hatta Boutique
}

\author{
Saifur Rohman Cholil, Tria Ardianita \\ ${ }^{1}$ Universitas Semarang, Jl. Soekarno Hatta, Semarang 59160,Indonesia
}

\section{ARTICLE INFORMATION}

Received: February $03^{\text {rd }}, 2021$

Revised: May $26^{\text {th }}, 2021$

Available online: September $30^{\text {th }}, 2021$

\section{KEYWORDS}

Country, costs, exhibition, research, AHP, MAUT

\section{CORRESPONDENCE}

Phone: +62 8562786874

E-mail: cholil@usm.ac.id

\section{A B S T $\mathbf{R}$ A $\mathbf{C}$ T}

This research was conducted with the aim of helping decide the destination country for overseas exhibitions at the Batik Hatta Boutique. By knowing all the data and information of a country, boutique owners can decide which country to visit in the batik exhibition. Because if you attend the cast in all countries, there will be overruns in costs. The methods used are AHP and MAUT. The AHP method is used as a weighting using a linguistic value scale. Weights are obtained from the pairwise comparison matrix between two elements of all elements that occur at the same hierarchical level. The MAUT method is used to determine the importance of each alternative for the ranking process.

The results of this study indicate that Cambodia was chosen as the location to be visited for the batik exhibition. The results of the validation using the Spearman Rank correlation comparison obtained a value of 0.951 meaning that this method can be used as a decision making.

\section{INTRODUCTION}

Batik is one of the cultural heritages from ancient times and has become a pride in Indonesia [1]. The creative form of batik is also a work of art made with patience, research with a long process. Batik has become a characteristic of Indonesia and has gained recognition from the world. Interational as Indonesia's cultural identity [2]. In addition, batik is also much-loved by other countries. Many exhibition activities about batik are carried out at home and abroad. Batik Hatta Boutique, especially for the problem of cost because they have to pay the maximum possible so as not to experience swelling. Batik Hatta Boutique is a BUMN UMKM shop which is specialized in manufacturing convection and fashion that focuses on the world of batik. The boutique is located on street Graha Mukti Raya No.361, Tlogosari Kulon, Pedurungan, Semarang.

The decision-making process for overseas exhibitions is still having difficulties, especially in the process of calculating and comparing the destination countries. The calculation that is done at this time is still using the manual method, this is of course less productive and time-consuming. Determination of criteria and alternatives is done by literature review and direct interviews with boutique owners before determining a number of countries that will be visited with an estimated minimum cost to be incurred.
The DSS model that will be applied to determine the destination country for overseas exhibitions is to use the Analitycal Hierarchy Process (AHP) - Multi-Attribute Utility Theory (MAUT) method. The combination of these two methods has been widely used to solve a problem. For example, to determine the dominant criteria in the strategy of developing the competitiveness of higher education based on information technology [3]. Many studies using the AHP method such as that conducted by [4] conducted a study to analyze the multi-criteria of large cargo transportation through cities whose highest priority is achieved by the T3 route with a value of 0.6750 . Research on the rheology of crumb rubber asphalt modified with binder and choose the best binder [5], selecting the optimal technology to rehabilitate pipes in water distribution systems [6]. The research by combining the AHP method with other methods including [7] research analyzes human factors of major coal mining accidents in China based on the HFACS-CM Model and the AHP method, and [8] a comparison of the AHP and FAHP methods in determining suitable areas for harvest drinking water in Iran's Birjand aquifer.

The MAUT method has been researched by [9] to determine the recipient of credit at PT. XYZ to minimize an error with a result of 13.33. Research with the same method was also carried out by [10] the influence of decision room information on MAUT-based systems to support the purchase decision process and to plan with preferences using Multi Attribute Utility Theory and Integral Choquet [11]. 
Other SPK research uses other methods such as in research [12] which uses the HYBRID method in determining the location of the stand in Batik Hatta Semarang with a total correlation value of the Spearman Rank of 0.90. Research by [13] with software reliability growth modeling with dynamic error and release time optimization using GA and MAUT.

From several studies that combine the AHP method and the MAUT method both in terms of usage and testing calculations. The method needed to solve the problem at the boutique. The AHP method is used to determine its weighting, and the MAUT method to determine its ranking. It is hoped that the construction of the SPK will be able to help the owner of the "Batik Hatta" boutique to consider all who estimate the cost of exhibitions in several countries and decide which countries to visit.

\section{METHOD}

\section{Types of research}

This research involves a quantitative method in which the method is used to test the hypothesis that has been made. All research data were obtained from the Batik Hatta Boutique.

\section{Method of collecting data}

The methods used in data collection related to this research are as follows:

\section{a) Interview}

The interview is a data collection technique that is carried out face-to-face and questions and answers between data collectors and sources. The informant involved is the owner of the Batik Hatta Boutique itself. This method was chosen in order to obtain accurate data and produce accountable output.

b) Observation

Observation or field study is a data collection technique by making direct observations of events, behaviors, and subjects that are systematically researched at Batik Hatta Boutique.

c) Literature study

Literature study is a method that is carried out by studying and collecting materials or information relating to the problem being researched.

A picture of the system flow in the form of a flowchart used in this SPK operation is shown in Figure 1.

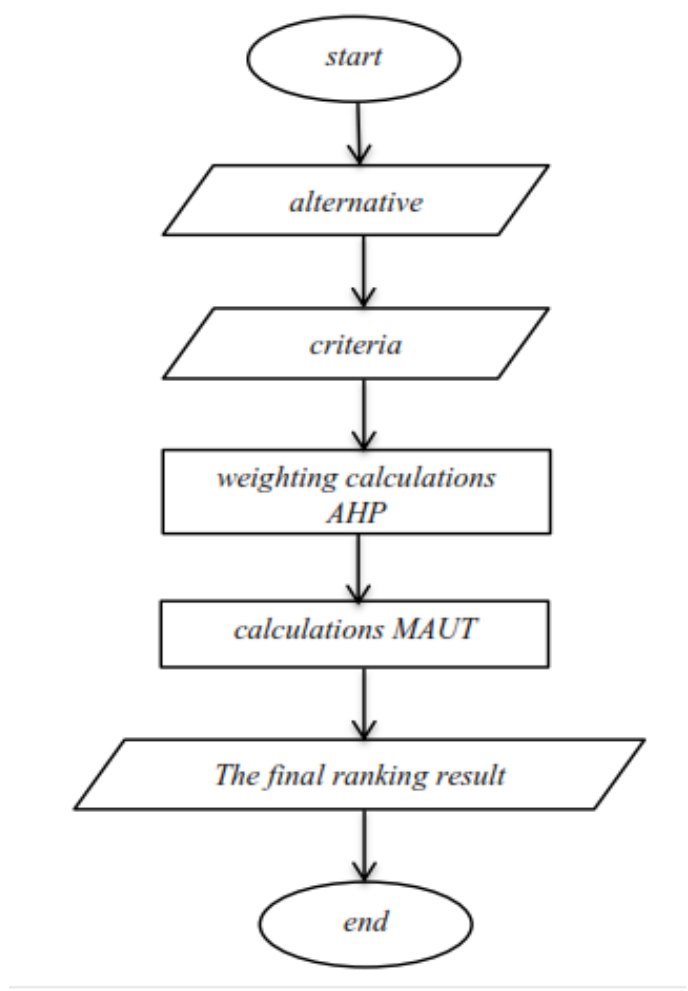

Figure 1. Flowchart flow system

\section{Analytic Hierarchy Process (AHP)}

AHP is a decision making method that involves a number of criteria and alternatives chosen based on consideration of all related criteria [10]. The advantage of AHP compared to other methods is that there is a hierarchical structure, so that it can reach the deepest sub-criteria, as a match of the selected criteria and can calculate validity to the limit of tolerance for inconsistencies in the alternatives and criteria chosen by the person making the decision. With the AHP method, a problem will be solved in a structured frame of mind, so that it can be applied for effective, multi-objective and multi-criteria decision making for the problem [10]. In this study, several criteria have been considered [11], namely transportation (C1), lodging (C2), distance (C3), baggage weight (C4), stand rental (C5). AHP calculation is done with the following stages:

1. Create a hierarchical structure based on criteria and alternatives.

2. Make a comparison matrix based on problems and priorities that affect each element. But for the criteria that are compared the same, it must produce a value of 1 .

3. Determine the eigen value by multiplying the weight obtained from normalization with the first total matrix.

4. Determine the Value of Consistency Index (CI) and Consistency Ratio (CR) [10].

$$
\begin{aligned}
& C I=\frac{\lambda m a k s-n}{n-1} \\
& C R=\frac{C I}{R I}
\end{aligned}
$$


Table 1. Random Index Consistency

\begin{tabular}{|c|c|c|c|c|c|c|c|}
\hline Orde & 1 & 2 & 3 & 4 & 5 & 6 & 7 \\
\hline RI & 0,00 & 0,00 & 0,58 & 0,90 & 1,12 & 1,24 & 1,32 \\
\hline
\end{tabular}

CR must be CONSISTENT value. If the result is equal to or less than 0.1, the calculation result can be declared correct. But if the result is more than 0.1 , then the calculation has to be repeated [4]. 5. Multiply the results of the alternative score matrix with weights. The weight value is obtained from the vector results divided by the number of matrices.

\section{Multi Attribute Utility Theory (MAUT)}

MAUT is a method used to carry out quantitative comparisons to combine different estimates of costs and risk benefits [12]. MAUT also includes a scheme whose final evaluation, $v(x)$, of an object $\mathrm{x}$ is defined as a weight added by a value that is relevant to its dimension value [7].

In the criteria contained in the alternative helps solve a problem [13]. To find an alternative desired by someone, it can be done a multiplication of superior values that have been set. So that using the MAUT method will provide a solution and approaching the alternative that will be taken into a solution. MAUT uses a numerical scale value of $0-1$ to replace multiple interests, 0 represents the worst choice and 1 for the best choice [6]. However, the final result can be a ranking order that has been made by decision makers from the evaluations that have been described. Evaluation values are defined as follows [14] :

$$
V(x)=\sum_{i=1}^{n} w j \cdot x i j
$$

Explanation :

$\mathrm{V}(\mathrm{x})$ is an evaluation value of a sub-criteria, then the weight value is determined from some i elements of the other elements. Whereas $\mathrm{n}$ is the sum of all elements. The total of all weight values is 1 .

The following stages in solving problems in the method [15]:

1. Take decision values with different dimensions.

2. Determine the value of alternative weights to each dimension.

3. Make a list of all alternatives.

4. Enter the utility value of each alternative in accordance with its attributes.

5. Doing utility multiplications with their respective weights to obtain alternative values.

Matrix normalization [14] :

$$
U(x)=\frac{x-x i^{-}}{x i^{+}-x i^{-}}
$$

Explanation :

$\mathrm{U}(\mathrm{x})=$ Utility value for normalization

$\mathrm{x}=$ Alternative weight

$\mathrm{x} \overline{1}=$ Lowest weight (minimum) of the criterion- $\mathrm{x}$

$x i_{+}=$Highest weight (maximum) of the criterion- $\mathrm{x}$

\section{RESULTS AND DISCUSSION}

This calculation research was tested to determine and formulate the objectives of the country to be selected for the exhibition using the AHP and MAUT methods. Here the AHP method is used to determine the weighting of criteria, while MAUT is used

54 Saifur Rohman Cholil to determine the importance of each alternative to the ranking process. To determine the criteria weights, the comparison of the matrix filling of each criterion is performed.

Table 2. Subcriterion Scale Values

\begin{tabular}{lccccccc}
\hline 8 & 9 & 10 & 11 & 12 & 13 & 14 & 15 \\
\hline 1,41 & 1,45 & 1,49 & 1,51 & 1,48 & 1,56 & 1,57 & 1,59 \\
\hline \multicolumn{1}{c}{ Linguistic Value } \\
\hline $1=$ Very Poor \\
$2=$ Less \\
$3=$ Enough \\
$4=$ Good \\
$5=$ Very Good
\end{tabular}

Table 3. Transportation Subcriterion Value

\begin{tabular}{ccc}
\hline \multicolumn{3}{c}{ sub transportation criteria $($ C1) } \\
\hline airplane A & $<1$ million - 2 million & 5 \\
airplane B & 2,1 million - 4 million & 4 \\
airplane C & 4,1 million $-5,9$ million & 3 \\
airplane D & 6 million - 8 million & 2 \\
airplane E & $>8$ million & 1 \\
\hline
\end{tabular}

Table 4. Value of Lodging Subcriterion

\begin{tabular}{ccc}
\hline & lodging sub criteria $(\mathbf{C 2})$ & \\
\hline hotel A & 1 million $-1,5$ million & 5 \\
hotel B & 1,6 million -3 million & 4 \\
hotel C & 3,1 million -4 million & 3 \\
hotel D & 4,1 million -5 million & 2 \\
hotel E & $>5$ million & 1 \\
\hline
\end{tabular}

Table 5. Distance Subcriterion Value

\begin{tabular}{cc}
\hline distance sub criteria $(\mathbf{C 3})$ & \\
\hline$<1 \mathrm{~km}$ & 5 \\
$2 \mathrm{~km}-3 \mathrm{~km}$ & 4 \\
$4 \mathrm{~km}-6 \mathrm{~km}$ & 3 \\
$7 \mathrm{~km}-10 \mathrm{~km}$ & 2 \\
$>10 \mathrm{~km}$ & 1 \\
\hline
\end{tabular}

Table 6. Baggage Weight Subcriterion Value

\begin{tabular}{cc}
\hline baggage sub criteria (C4) & \\
\hline$>45 \mathrm{~kg}$ & 5 \\
$35 \mathrm{~kg}-40 \mathrm{~kg}$ & 4 \\
$25 \mathrm{~kg}-30 \mathrm{~kg}$ & 3 \\
$15 \mathrm{~kg}-20 \mathrm{~kg}$ & 2 \\
$5 \mathrm{~kg}-10 \mathrm{~kg}$ & 1 \\
\hline
\end{tabular}

Table 7. Value of Rent Stand Subcriterion

\begin{tabular}{cc}
\hline sub-stand rental criteria (C5) & \\
\hline$<1$ million & 5 \\
$1,1-2$ million & 4 \\
$2,1-3,9$ million & 3 \\
$4-7$ million & 2 \\
$7,1-10$ million & 1 \\
\hline
\end{tabular}

Table 8. Comparison Matrix Value

\begin{tabular}{cccccc}
\hline & C1 & C2 & C3 & C4 & C5 \\
\hline C1 & $\mathbf{1}$ & 0,5 & 0,2 & 0,3 & 0,143 \\
& \multicolumn{2}{c}{ https://doi.org/10.25077/jitce. $5.02 .52-56.2021$} \\
\end{tabular}




\begin{tabular}{rccccc}
$\mathbf{C 2}$ & 2 & $\mathbf{1}$ & 0,33 & 0,3 & 0,5 \\
$\mathbf{C 3}$ & 5 & 3 & $\mathbf{1}$ & 0.5 & 0,33 \\
$\mathbf{C 4}$ & 3 & 4 & 2 & $\mathbf{1}$ & 0,5 \\
$\mathbf{C 5}$ & 7 & 2 & 3 & 2 & $\mathbf{1}$ \\
\hline Total & 18 & 10,5 & 6,53 & 4,08 & 2,48 \\
\hline
\end{tabular}

For the results of the normalization calculation carried out by dividing the number of each element by the number of rows, $P$. Vector is obtained from the sum of each row.

Table 9. Normalization and Vector Results

\begin{tabular}{lrrrrr}
\hline & C1 & C2 & C3 & C4 & C5 \\
\hline C1 & 0,056 & 0,048 & 0,031 & 0,082 & 0,058 \\
C2 & 0,111 & 0,095 & 0,051 & 0,061 & 0,202 \\
C3 & 0,278 & 0,286 & 0,153 & 0,122 & 0,135 \\
C4 & 0,167 & 0,381 & 0,306 & 0,245 & 0,202 \\
C5 & 0,389 & 0,190 & 0,459 & 0,490 & 0,404 \\
\hline
\end{tabular}

P.Vector Value $=0,273 ; 0,521 ; 0,974 ; 1,301 ; 1,932$

Weight values can be obtained from P.vector that has been sought previously then divided by the number (n) matrices.

$$
\begin{aligned}
& \mathrm{C} 1=0,273 / 5=0,055 \\
& \mathrm{C} 2=0,521 / 5=0,104 \\
& \mathrm{C} 3=0,974 / 5=0,195 \\
& \mathrm{C} 4=1,301 / 5=0,260 \\
& \mathrm{C} 5=1,932 / 5=0,386
\end{aligned}
$$

After weighting for each criterion has been obtained and has proven its consistency, the next step is to determine the importance of each alternative to the ranking process by using the MAUT method. The alternatives used are A1 = Vietnam; $\mathrm{A} 2=$ Singapore; A3 = Philippines; A4 = Cambodia; A5 = Laos; A6 = Thailand; A7 = Macau; A8 = Korea; A9 = Paris France; A10 = Myanmar. The result of normalization is done by involving the maximum weight and minimum weight.

Table 10. Matrix of Interest for Every Alternative

\begin{tabular}{lccccc}
\hline & C1 & C2 & C3 & C4 & C5 \\
\hline A1 & 1 & 3 & 3 & 4 & 4 \\
A2 & 5 & 4 & 5 & 2 & 1 \\
A3 & 4 & 4 & 4 & 4 & 3 \\
A4 & 4 & 4 & 5 & 4 & 4 \\
A5 & 1 & 4 & 3 & 4 & 4 \\
A6 & 3 & 2 & 4 & 3 & 4 \\
A7 & 4 & 3 & 3 & 4 & 3 \\
A8 & 4 & 4 & 3 & 2 & 2 \\
A9 & 3 & 4 & 3 & 2 & 2 \\
A10 & 1 & 3 & 2 & 3 & 5 \\
\hline
\end{tabular}

Based on Table 10. the results of matrix normalization can be determined which can be seen in Table 11.

Table 11. Matrix Normalization Results

\begin{tabular}{cccccc}
\hline & C1 & C2 & C3 & C4 & C5 \\
\hline A1 & 0 & 0 & 0 & 1 & 1 \\
A2 & 1 & 1 & 1 & 0 & 0 \\
A3 & 0,75 & 1 & 0,5 & 1 & 0,67 \\
A4 & 0,75 & 1 & 1 & 1 & 1 \\
A5 & 0 & 1 & 0 & 1 & 1 \\
A6 & 0,5 & 0 & 0,67 & 0,5 & 0,75 \\
A7 & 0,75 & 0,5 & 0,33 & 1 & 0,5 \\
A8 & 0,75 & 1 & 0,33 & 0 & 0,25
\end{tabular}

\begin{tabular}{cccccc} 
A9 & 0,5 & 1 & 0,33 & 0 & 0,25 \\
A10 & 0 & 0,5 & 0 & 0,5 & 1 \\
\hline
\end{tabular}

Weighted normalized results obtained from the multiplication between AHP Weight and MAUT Normalization Results.

$\mathbf{A 1}=(0,055 \times 0)+(0,104 \times 0)+(0,195 \times 0)+(0,260 \times 1)+(0,386$ x 1) $=0,667$

$\mathbf{A 2}=(0,055 \times 1)+(0,104 \times 1)+(0,195 \times 1)+(0,260 \times 0)+(0,386$ $\mathrm{x} 0)=0,353$

$\mathbf{A 3}=(0,055 \times 0,75)+(0,104 \times 1)+(0,195 \times 0,5)+(0,260 \times 1)+$ $(0,386 \times 0,67)=0,728$

$\mathbf{A 4}=(0,055 \times 0,75)+(0,104 \times 1)+(0,195 \times 1)+(0,260 \times 1)+$ $(0,386 \times 1)=0,890$

A5 $=(0,055 \times 0)+(0,104 \times 1)+(0,195 \times 0)+(0,260 \times 1)+(0,386$ $\mathrm{x} 1)=0,719$

$\mathbf{A 6}=(0,055 \times 0,5)+(0,104 \times 0)+(0,195 \times 0,67)+(0,260 \times 0,5)$ $+(0,386 \times 0,75)=0,577$

$\mathbf{A} 7=(0,055 \times 0,75)+(0,104 \times 0,5)+(0,195 \times 0,33)+(0,260 \times$ 1) $+(0,386 \times 0,5)=0,611$

$\mathbf{A 8}=(0,055 \times 0,75)+(0,104 \times 1)+(0,195 \times 0,33)+(0,260 \times 0)$ $+(0,386 \times 0,25)=0,307$

A9 $=(0,055 \times 0,5)+(0,104 \times 1)+(0,195 \times 0,33)+(0,260 \times 0)+$ $(0,386 \times 0,25)=0,293$

$\mathbf{A 1 0}=(0,055 \times 0)+(0,104 \times 0,5)+(0,195 \times 0)+(0,260 \times 0,5)+$ $(0,386 \times 1)=0,569$

Determine the ranking obtained by comparing the final value from A1 to A10, it can be concluded that the highest value is A4 (Cambodia). So that the A4 alternative which has been chosen as the country to be visited for the batik exhibition.

Table 12. Spearman Rank Correlation Test Results

\begin{tabular}{ccccc}
\hline Alt & $\begin{array}{c}\text { Total } \\
\text { Alternative }\end{array}$ & Ranking & $\begin{array}{c}\text { History } \\
\text { (Manual) }\end{array}$ \\
\hline A1 & 0,667 & 4 & 3 & 1 \\
A2 & 0,353 & 8 & 7 & 1 \\
A3 & 0,728 & 2 & 2 & 0 \\
A4 & 0,890 & 1 & 1 & 0 \\
A5 & 0,719 & 3 & 2 & 1 \\
A6 & 0,577 & 6 & 5 & 1 \\
A7 & 0,611 & 5 & 4 & 1 \\
A8 & 0,307 & 9 & 8 & 1 \\
A9 & 0,293 & 10 & 9 & 1 \\
A10 & 0,569 & 7 & 6 & 1 \\
\hline & \multicolumn{4}{c}{ Spearman Rank Validation $=\mathbf{0 , 9 5 1}$} \\
\hline
\end{tabular}

With the Spearman Rank correlation test, a value of 0,951 can be obtained. This proves the suitability of the calculation with the AHP - MAUT method with manual calculations performed by the boutique owner. 


\section{CONCLUSIONS}

From the results of the research and calculations that have been carried out, the AHP - MAUT method can provide problem solving solutions in determining the decision of the destination country for overseas exhibitions at the Batik Hatta Boutique. Based on the results that have been obtained, it shows that Cambodia was selected as the main alternative to be visited in the batik exhibition. The result of the Spearman Rank correlation test value obtained by a value of 0.951 means that this method can be used to determine the objectives of exhibitions in a country.

\section{REFERENCES}

[1] A. Prasetyo and Singgih, "Karakteristik Motif Batik Kendal Interpretasi dari Wilayah dan Letak Geografis," Imajin. J. Seni, vol. 10, no. 1, pp. 51-60, 2016.

[2] I. K. Iskandar and Eny, "Batik Sebagai Identitas Kultural Indonesia Di Era Globalisasi,” pp. 2456-2472, 2017.

[3] Y. Yulmaini, A. Sanusi, and M. A. E. Yusendra, "The Implementation of AHP for Determining Dominant Criteria in Higher Education Competitiveness Development Strategy Based on Information Technology," Int. J. Artif. Intell. Res., vol. 3, no. 1, 2018.

[4] F. Frieyadie and S. M. Ramadhan, "Penerapan Metode AHP Untuk Membantu Siswa Memilih Jurusan Yang Tepat Di SMK," J. RESTI (Rekayasa Sist. dan Teknol. Informasi), vol. 2, no. 3, pp. 662-667, 2018.

[5] E. Rosiska, "Penerapan Metode Analitycal Hierarchy Process (AHP) dalam Menentukan Mitra Usaha Berprestasi," J. RESTI (Rekayasa Sist. dan Teknol. Informasi), vol. 2, no. 2, pp. 479-485, 2018.

[6] A. Ramadiani, ramadiani ; Rahmah, "Sistem Pendukung Keputusan Pemilihan Tenaga Kesehatan Teladan,” J. Ilm. Teknol. Sist. Inf., vol. 3, no. 2, pp. 83-88, 2019.

[7] N. Hadinata, "Implementasi Metode Multi Attribute Utility Theory (MAUT) Pada Sistem Pendukung Keputusan dalam Menentukan Penerima Kredit," vol. 07, no. September, pp. 87-92, 2018.

[8] T. Imandasari and A. P. Windarto, "Sistem Pendukung Keputusan dalam Merekomendasikan Unit Terbaik di PDAM Tirta Lihou Menggunakan Metode Promethee," J. Teknol. dan Sist. Komput., vol. 5, no. 4, p. 159, 2017.

[9] S. R. Cholil, A. P. R. Pinem, and V. Vydia, "Implementasi metode Simple Multi Attribute Rating Technique untuk penentuan prioritas rehabilitasi dan rekonstruksi pascabencana alam," Regist. J. Ilm. Teknol. Sist. Inf., vol. 4, no. 1, p. 1, 2018.

[10] U. Arumi, Endah Ratna; Yudhatama, "Pemanfaatan Curiculum Vitae dan Sasaran Kinerja Pegawai untuk Penilaian Kinerja Dosen Menggunakan AHP," vol. 1, no. 1, pp. 19-25, 2017.

[11] M. Gemain, "Bagaimana Memilih UKM- UKM untuk Berpartisipasi di dalam Pameran-Pameran Perdagangan Kanada," no. November, 2016.

[12] S. Fajarika, "Sistem Pendukung Keputusan Pemilihan Balita Sehat Se-Kecamatan Sei Lepan Menggunakan Metode Multi Atributte Utility Theory (Maut) (Studi Kasus: Puskesmas Desa Lama)," KOMIK (Konferensi Nas. Teknol. Inf. dan Komputer), vol. 3, no. 1, pp. 515-521,
2019.

[13] P. Kailiponi, "Analyzing evacuation decisions using multiattribute utility theory (MAUT)," Procedia Eng., vol. 3, pp. 163-174, 2010.

[14] M. Hidayat and P. A. Jusia, "Analisa dan Perancangan Sistem Pendukung Keputusan Untuk Penerimaan Karyawan PT . Dos Ni Roha Jambi Menggunakan Metode MAUT ( Multi Attribute Utility Theory )," vol. 13, no. 1, 2018.

[15] J. Nasution and M. Syahrizal, "Sistem Pendukung Keputusan Rekomendasi Calon Kepala Puskesmas Mengunakan Metode Multi Attribute Utility Theory (Maut) (Studi Kasus: Puskesmas Desa Lama Sei Lepan)," KOMIK (Konferensi Nas. Teknol. Inf. dan Komputer), vol. 3, no. 1, pp. 176-182, 2019. 